\title{
REVIEW
}

\section{Ruth Langer \\ Cursing the Christians? A History of the Birkat HaMinim}

(Oxford and New York: Oxford University Press, 2012), hardcover, 389 pp.

Clemens Leonhard, University of Münster

Cursing the Christians? discusses the history and the broad array of meanings of one of the most controversial and unstable Jewish prayers, the so-called "blessing"-a euphemism for the "curse"- "of the heretics," which is found in the Amidah (standing prayer) of the weekday liturgy. Even if the occasional visitor to a Sabbath or festival synagogue service may not be exposed to this prayer, it plays a role of paramount importance in the history of the relationship between Judaism and Christianity. While this "blessing" did not emerge as a specifically anti-Christian curse, it is clear that some Jews and Christians interpreted this prayer as such later on. In this book, Langer illustrates the multifarious historical meanings of the different forms of this text, which also reflect the rich humanistic heritage of Judaism.

The book is divided into two parts. In the first half (pp. 3-181) Langer provides a concise description of the history of the birkat haminim and diverse formulations of it. In the second half (pp. 187-254) Langer presents the data on which her conclusions and descriptions are based. Five appendices give critical editions of the various versions of the prayer. An extensive apparatus of notes as well as a glossary, a comprehensive bibliography, and elaborate indexes guide the readers through more complex aspects of the discussion. Thus, the book is both a history of this prayer and a rich archive of sources and their interpretation. Langer's arguments are presented clearly and well-structured. She discusses other opinions equitably, concisely, but with sufficient sophistication. She does not make extensive use of technical terminology and explains her presuppositions. The brevity of her presentation has its price. Readers are advised to equip themselves with translations of the Talmud and to be prepared to read some paragraphs twice. Consequently, they will be drawn into an intriguing scholarly narrative and rewarded greatly for their efforts.

Langer's methods for studying the highly diverse versions are impressive. After all, forms of this prayer originated in the first half of the first millennium and versions were continuously recited until today. The few rabbinic and patristic texts that seem to hint at the blessing do not yield reliable data about its origins. The birkat haminim and many other sources for the development of Jewish (and Christian) liturgies of late Antiquity must be reconstructed on the basis of later manuscripts or dubious sources, like short polemical remarks by ancient Christian authors about what "the Jews"-perhaps from their time, perhaps from earlier generations-are allegedly doing in their synagogues. Langer rightly emphasizes that there is no ground for reconstructing any form of the prayer antedating the Middle Ages. Thus, the paucity of early sources is in stark contrast to the overwhelming range of later material, especially versions found in the Cairo Geniza.

Nearly every written or printed version of the Amidah as well as literature that expounds aspects of the prayer book and halakhic (legal) treatments of the prayers are sources for Langer's study. 
She masterfully generates plausible hypotheses for the early times for which little data is available and retains control of the complex history of the great number of later texts. She argues that liturgical texts are not transmitted as texts that must be preserved unchanged (like the Hebrew Bible). Rather, they are adapted to later Jews' own needs. These adaptations are found in actual liturgical texts and influence ideas about ideal liturgical practices and reconstructed liturgical practices of a past epoch. Finally, some Jews, to avoid censorship, altered prayers for use in printed books. Langer also gathers material that shatters facile assumptions about the social impact of this prayer. For example, she notes the differences between the versions from Islamic and Christian contexts and the absence of any known Muslim reactions to the birkat haminim (even with the inclusion of several categories of "evildoers" that might have provoked Muslims too).

Langer's book has important implications for contemporary theological thinking about the relationship between Jews and Christians, their perceptions of each other, and their willingness to grapple with a most troubling past, as is evident in their liturgies. The birkat haminim is studied by modern scholars who are members of the religious communities that inherited the memories of their past conflicts. Against Christian assumptions that Judaism is an outdated and petrified remnant of a much earlier era, Langer's study of Jewish liturgy demonstrates that Judaism was and is a thriving religious system. Jews were and are prepared to change their liturgies and customs and have always remained alert observers of their social contexts.

In her short afterword on modern discussions of the birkat haminim (pp. 183-85), Langer points out how Jews went to great lengths to reassess their relationship toward Christianity already many decades before the path-breaking statement Nostra Aetate on Judaism at the Second Vatican Council from 1965. Just as this statement and others illustrate efforts by the Catholic Church (and other churches which offered similar statements) to rethink relations with Jews, Langer shows how some Jews minimized the anti-Christian aspects of the birkat haminim in the last few centuries out of conciliatory and humanistic motives. This is a contrast to earlier times, when Jewish scholars produced apologetic explanations that the text was not directed against Christians.

Cursing the Christians? is first-class liturgical scholarship and makes a powerful theological statement about modern Jewish-Christian relations. The book will be of interest to a variegated readership. It is the best and most comprehensive treatment of its subject available today and will remain the magisterial study of this topic for a long time. 